\title{
A Mutant of Pseudomonas aeruginosa Deficient in an ATP-dependent Deoxyribonuclease
}

\author{
By P. R. LEHRBACH, C. D. DIRCKZE AND B. T. O. LEE* \\ Department of Genetics, University of Melbourne, Parkville, Victoria 3052, Australia
}

(Received 24 January 1980)

\begin{abstract}
A mutant of Pseudomonas aeruginosa PAOl originally isolated on the basis of its sensitivity to methyl methanesulphonate was found to be (i) sensitive to u.v.- and $\gamma$-irradiation, (ii) deficient in recombination as assayed by transduction and conjugation and (iii) deficient in an ATP-dependent deoxyribonuclease activity. Its marker ( $m m s-13)$ is cotransducible with $\arg B$ and $\operatorname{pyr} E$ which are mapped at approximately $22 \mathrm{~min}$ on the $P$. aeruginosa chromosome.
\end{abstract}

\section{INTRODUCTION}

Observations from various bacterial species suggest that an ATP-dependent deoxyribonuclease plays a role in recombination. It has been shown that $\mathrm{rec} B$ and $\mathrm{rec} C$ recombinationdeficient mutants of Escherichia coli lack this activity (Buttin \& Wright, 1968; Barbour \& Clark, 1970); mutants of Diplococcus pneumoniae (Vovis \& Buttin, 1970a, b) and Haemophilus influenzae (Greth \& Chevallier, 1973; Wilcox \& Smith, 1975) lacking an ATPdependent nucleolytic activity are transformation-deficient; also a recombination-deficient strain of Bacillus subtilis showed reduced levels of a similar DNAase activity (Doly et al., 1974).

An ATP-dependent DNAase has been characterized from Pseudomonas aeruginosa strain PAO (Miller \& Clark, 1976). This activity has an absolute dependence on the presence of ATP and double-stranded DNA. The activity is enhanced at $\mathrm{Mg}^{2+}$ concentrations of approximately $10 \mathrm{~mm}$. The enzyme reduces double-stranded linear DNA to acid-soluble products consisting of short oligonucleotides of from one to six bases in length. The ATPdependent DNAase of $P$. aeruginosa does not attack denatured DNA either endonucleolytically or exonucleolytically and in this respect it is different from the ATP-dependent nuclease activity in $E$. coli (Oishi, 1969) and $H$. influenzae (Friedman \& Smith, 1972) but is similar to enzymes from Micrococcus luteus (Van Dorp et al., 1974), B. subtilis (Ohi \& Sueoka, 1973) and D. pneumoniae (Vovis \& Buttin, 1970a,b).

Mutants deficient in ATP-dependent DNAase from various bacterial species also showed increased sensitivity to the chemical mutagen methyl methanesulphonate (MMS) (Mazza et al., 1975). In addition, the ATP-dependent DNAase mutants of $H$. influenzae show increased sensitivity to mitomycin C and deoxycholate (Kooistra et al., 1976; Small et al, 1976; Setlow, 1977). We assayed for ATP-dependent DNAase activity among various MMS-sensitive mutants of $P$. aeruginosa which had been classified into eight phenotypic groups on the basis of their cross-sensitivity to u.v.- and $\gamma$-irradiation, treatment with $N$-methyl- $N^{\prime}$-nitro- $N$-nitrosoguanidine (NG) and their ability to reactivate u.v.- and MMStreated bacteriophage E79 (Kung \& Lee, 1973). The results indicate a deficiency of the ATPdependent DNAase activity in one phenotypic group 5 mutant, GMB143. Group 5 mutants are sensitive to u.v., MMS and NG but show wild-type ability to reactivate u.v.- or MMS- 


\section{Table 1. Bacterial strains}

Strain no.

PAO1

PAO287*

GMA856

GMA862

GMA941

GMB143

GMB114

GMB117

GMA943

GMB112

GMA852

GMB110

GMB119

GMB122

GMB147

PAO2001

PAO2002

$\mathrm{PAO} 2003$

GMC166

GMC182

PAO486

PAO170

JC9006
Strain characteristics

prototrophic $\mathrm{chl}-2$

his-12 met-28 ilv-202 argB1 str-1

uvr-18 (group 3)

uvr-24 (group 4)

his-104 uvr-104 (group 5)

mms-13 (group 5)

$m m s-22$ (group 5)

$m m s-43$ (group 5)

thr-5431 uvr-107 (group 6)

polA3 (group 7)

uvr-14 (group 8)

$m m s-3$ (group 11)

ilv-53 mms-53 (group 11)

mms-79 (group 11)

hcr-10 (group 12)

argH32 str-39 chl-2 FP-

argH 32 str-39 chl-2 rec-1 $\mathrm{FP}^{-}$

argH32 str-39 chl-2 rec-2 FP-

his-12 met-28 ilv-202 mms-13 str-1

his-12 argB1 pyrE str-1

pyrE79 cml-2 rif-19 FP-

leu-38 FP2

pur-600
Reference

Holloway (1955)

Stanisich \& Holloway (1969)

[GMA142; Mee \& Lee, 1969]

Kung \& Lee (1973)

Kung \& Lee (1973)

Kung \& Lee (1973)

Kung \& Lee (1973)

Kung \& Lee (1973)

Kung \& Lee (1973)

Kung \& Lee (1973)

Kung \& Lee (1973)

Kung \& Lee (1973)

Kung \& Lee (1973)

Kung \& Lee (1973)

Kung \& Lee (1973)

Kung \& Lee (1973)

Chandler \& Krishnapillai (1974)

Chandler \& Krishnapillai (1974)

Chandler \& Krishnapillai (1974)

This study

This study

Holloway (1978)

Kung \& Lee (1975)

Pemberton \& Clark (1973)

* his-12 is the same as his-2 (Stanisich \& Holloway, 1969) and his-52 (Mee \& Lee, 1969) and is a member of the hisI group (Mee \& Lee, 1969) not the hisI group as stated by Holloway et al. (1979).

treated bacteriophage E79. The phenotypic characterization of this mutant and the genetic location of its marker are reported in this paper.

\section{METHODS}

Bacteria. The standard wild-type strain is Pseudomonas aeruginosa PAO1 (ATCC 15692) (Holloway, 1955). Strains used in this study are listed in Table 1.

General culture procedures, MMS treatment, u.v.-irradiation and $\gamma$-irradiation. These techniques have been described previously (Kung \& Lee, 1973; Lehrbach et al., 1976, 1977).

Chemicals. Methyl methanesulphonate (MMS) was obtained from Eastman Chemical Co.; $\left[2-{ }^{3} \mathrm{H}\right]$ adenine from The Radiochemical Centre, Amersham; bovine serum albumin from Calbiochem; calf thymus DNA and ATP from Sigma.

Transduction analysis. Transductions were carried out as described by Mee \& Lee (1967) except that phage G101 was used.

FP2 conjugation analysis. Cultures of donor and recipient strains in the exponential growth phase were mixed in equal proportions. The mating mixture was incubated for $2 \mathrm{~h}$ without shaking in a sterile Petri plate at $37^{\circ} \mathrm{C}$. Saline-washed samples of the mating mixture were then plated on selective agar medium. Streptomycin $\left(200 \mu \mathrm{g} \mathrm{ml}^{-1}\right)$ was used as a counter-selecting agent. Control samples of the donor and recipient strains were also plated on selective plates. Plates were incubated at $37^{\circ} \mathrm{C}$ for 24 to $48 \mathrm{~h}$ before recombinants were selected for further analysis.

Determination of percentage viability. A Petroff-Hauser bacterial counting chamber was used to determine the total number of cells in $1 \mathrm{ml}$ culture medium under dark-field microscopic observation at a magnification of 400 . Viable cells were counted by diluting and plating on nutrient agar plates. These observations were made on exponential phase cultures sampled over $5 \mathrm{~h}$. The ratio of the concentration of viable cells to the concentration of total cells was determined.

Preparation of cell-free extracts. Extracts were prepared by a modification of the method originally described by Miller \& Clark (1976). Strains were grown in $500 \mathrm{ml}$ M9 medium supplemented with glucose and Casamino acids (Barbour \& Clark, 1970) until late-exponential phase. The cells were harvested by centrifugation, washed in $20 \mathrm{ml} 0.85 \%(\mathrm{w} / \mathrm{v})$ saline and resuspended in $20 \mathrm{ml} \mathrm{10 \% (w/v)} \mathrm{sucrose} \mathrm{solution} \mathrm{prepared} \mathrm{in}$ 
$0.5 \mathrm{M}$-Tris/ $\mathrm{HCl}$ buffer ( $\mathrm{pH} \mathrm{7.5).} \mathrm{This} \mathrm{suspension} \mathrm{was} \mathrm{frozen} \mathrm{in} \mathrm{liquid} \mathrm{nitrogen} \mathrm{and} \mathrm{thawed} \mathrm{at} \mathrm{room} \mathrm{tempera-}$ ture. To 1 vol. of this solution 0.1 vol. lysozyme $\left(2 \mathrm{mg} \mathrm{ml}^{-1}\right)$ and $0 \cdot 1$ vol. $1 \mathrm{M}-\mathrm{NaCl}$ were added and the mixture was kept at $0^{\circ} \mathrm{C}$ for $90 \mathrm{~min}$. Subsequent steps were carried out at temperatures not exceeding $4^{\circ} \mathrm{C}$. Cell debris was removed by centrifugation for $20 \mathrm{~min}$ at $48000 \mathrm{~g}$. A precipitate formed during dialysis was removed by centrifugation. The supernatant was used directly in nuclease assays or stored at $-70^{\circ} \mathrm{C}$.

DNA labelling procedure. Pseudomonas aeruginosa strain JC9006 was used to obtain $\left[2-{ }^{3} \mathrm{H}\right]$ adeninelabelled DNA. The method used was similar to that described by Pemberton \& Clark (1973) except that the cells were lysed with $5 \%(\mathrm{v} / \mathrm{v})$ Triton X100 (Sigma) in $50 \mathrm{~mm}$-Tris/HCl containing 60 mM-EDTA (pH 8). The DNA was extracted with chloroform/phenol/isoamyl alcohol (50:50:1, by vol.) equilibrated with $20 \mathrm{~mm}$-Tris/HCl containing $50 \mathrm{~mm}$-EDTA (pH 7.5).

Nuclease assay with duplex $D N A$. Nuclease activity on duplex DNA was measured by release of trichloroacetic acid-soluble fragments from native DNA. The reaction mixture $(0.81 \mathrm{ml})$ included Tris $/ \mathrm{HCl}(10 \mathrm{mM}$, pH 8.0), $\beta$-mercaptoethanol (10 mM), ATP (40 $\mu \mathrm{M}), \mathrm{MgSO}_{4}(10 \mathrm{mM}),\left[{ }^{3} \mathrm{H}\right] \mathrm{DNA}\left(0 \cdot 12 \mu \mathrm{g} \mathrm{ml}^{-1}\right.$, final concentration) and enzyme solution ( $700 \mu \mathrm{g}$ protein). The assays were carried out for $30 \mathrm{~min}$ at $37^{\circ} \mathrm{C}$. At intervals the reaction mixture was placed on ice and $0.4 \mathrm{ml}$ calf thymus DNA solution $\left(3.5 \mathrm{mg} \mathrm{ml}^{-1}\right)$ was added followed by $0.5 \mathrm{ml}$ cold $10 \%$ trichloroacetic acid. After 20 min the samples were centrifuged for $10 \mathrm{~min}$ at $12000 \mathrm{~g}$. Radioactivity in a $\mathbf{0 . 2} \mathrm{ml}$ sample of the supernatant fluid was counted in a Searle, Isocap 300 scintillation counter. Control reactions were carried out in the absence of ATP and with heat-treated $\left(90^{\circ} \mathrm{C}\right.$ for $\left.15 \mathrm{~min}\right)$ cell extracts.

Scintillation fluid was used as described previously (Miller \& Clark, 1976). Protein was determined by the method of Lowry using bovine serum albumin as a standard. DNA concentrations were determined by the method of Allen (1940).

\section{RESULTS AND DISCUSSION}

\section{Nuclease activity of various MMS-sensitive mutants}

Since mutants deficient in ATP-dependent DNAase activity have been shown to be sensitive to MMS, we screened a range of MMS-sensitive mutants of $P$. aeruginosa for this activity. Members of the phenotypic groups 3, 4, 5, 6, 7, 8, 11 and 12 (see Table 1), which are MMS-sensitive mutants previously defined on the basis of their cross-sensitivity to u.v.- and $\gamma$-irradiation, treatment with NG and their ability to reactivate u.v.- and MMS-treated bacteriophage E79 (Kung \& Lee, 1973), and the recombination-deficient mutants PAO2002 and PAO2003, which are also MMS-sensitive (Chandler \& Krishnapillai, 1974), were tested and the activities in cell-free extracts of these strains were compared with that of wild-type PAO1. Little activity was detected in strain GMB143 compared with PAO1 (Fig. 1), whereas all other strains tested showed activity similar to that of PAO1 (results not shown). To rule out the presence of an inhibitor of ATP-dependent DNAase in GMB143, extracts of mutant and wild-type PAO1 cells were mixed and assayed for nucleolytic activity. No significant inhibition of the wild-type extract by that of GMB143 was observed. All other strains in group 5 (Kung \& Lee, 1973) tested showed wild-type levels of ATP-dependent nuclease activity, so it is considered that this group is genetically heterogeneous although all are sensitive to u.v., MMS and NG and show wild-type ability to reactivate u.v.- or MMS-treated bacteriophage E79. This is supported by the map locations of the various MMS-sensitive alleles of this group (Kung \& Lee, 1975; P. R. Lehrbach, unpublished results).

The MMS-sensitive mutant GMB143 found to be deficient in ATP-dependent DNAase activity was further tested for its response to u.v.- and $\gamma$-irradiation and treatment with MMS. The effect of this mutant allele ( $m m s-13)$ on recombination ability was tested following conjugation (FP2) and transduction (phage G101). The mutant allele (mms-13) responsible for the properties observed was mapped, by conjugation and transduction techniques, in relation to previously located auxotrophic markers on the $P$. aeruginosa chromosome (Holloway et al., 1979). 


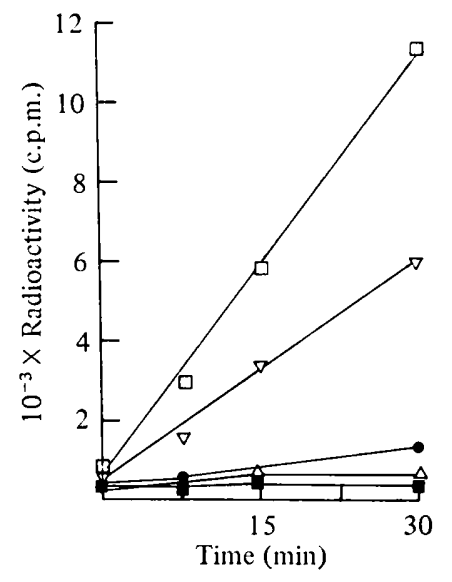

Fig. 1. ATP-dependent DNAase activity in cell-free extracts of $P$. aeruginosa strains: $\square$, PAO1; $\triangle$, GMB143; $\mathbf{\square}$ PAO1 (-ATP);, PAO1 (+ heat); $\nabla$, PAO1 + GMB143.
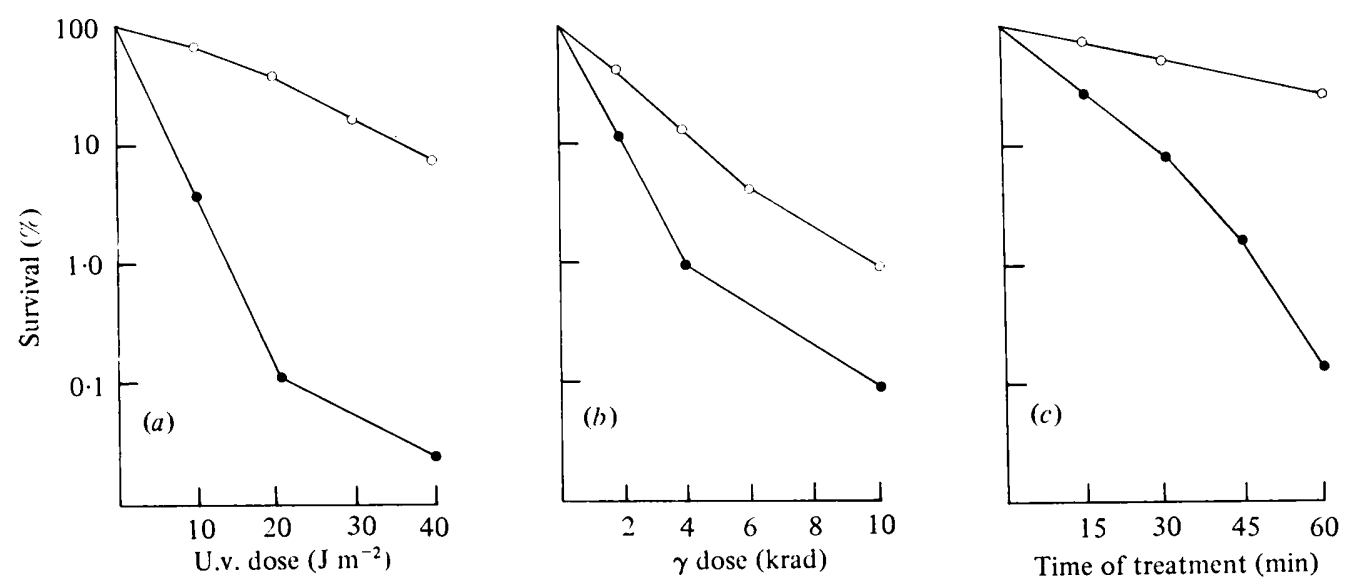

Fig. 2. Effect of various treatments on survival of $P$. aeruginosa wild-type PAO1 $(O)$ and MMSsensitive mutant GMB143 (O): (a) u.v.-irradiation; (b) $\gamma$-irradiation; (c) MMS treatment (8.5 mM).

\section{Radiation and chemical-mutagen sensitivity}

Strain GMB143 was originally isolated as an MMS-sensitive mutant of strain PAO1 which showed cross-sensitivity to both NG and u.v.-irradiation (Kung \& Lee, 1973). Survival curves of the parental strain PAO1 and GMB143 after exposure to u.v.-irradiation, $\gamma$-irradiation and MMS treatment are presented in Fig. 2. Strain GMB143 showed increased sensitivity to u.v.-irradiation and MMS treatment as previously reported (Kung \& Lee, 1973). We have further found that GMB143 is slightly sensitive to $\gamma$-irradiation. The ability of GMB143 to carry out host cell reactivation of u.v.-irradiated, $\gamma$-irradiated and MMStreated phage E79 was similar to that of wild-type PAO1 (Kung \& Lee, 1973; and unpublished results).

\section{Genetic analysis}

To locate the marker (mms-13) determining radiation sensitivity and ATP-dependent nuclease deficiency, the coinheritance of the $m m s-13$ phenotype (detected by MMS-sensitivity) with various auxotrophic markers was measured (Table 2). Strain GMB143 carrying the sex factor FP2 was mated with PAO287 and $\mathrm{his}^{+}, \mathrm{arg}^{+}, \mathrm{ilv}^{+}$and $\mathrm{met}^{+}$recombinants 
Table 2. Analysis of his ${ }^{+}$, arg $^{+}$, ilv $^{+}$and met $^{+}$recombinants for coinheritance of the unselected marker mms-13

\begin{tabular}{|c|c|c|c|c|}
\hline \multirow{2}{*}{$\begin{array}{c}\text { Mating } \\
\text { GMB143(FP) } \\
\times \text { PAO287 }\end{array}$} & \multicolumn{2}{|c|}{$\begin{array}{c}\text { Selected marker } \\
\text { (map location, } \\
\text { min) }\end{array}$} & \multirow{2}{*}{$\begin{array}{c}\text { Coinheritance of } \\
\text { unselected marker } \\
m m s-13(\%) \\
0 \cdot 7 \\
74 \\
25\end{array}$} & $\begin{array}{c}\begin{array}{c}\text { No. of } \\
\text { colonies } \\
\text { tested }\end{array} \\
284\end{array}$ \\
\hline & $\begin{array}{l}\text { his-12+ } \\
\operatorname{argB1} 1^{+} \\
\text {ilv-202 } \\
m e t-28^{+}\end{array}$ & $\begin{array}{l}(12) \\
(21) \\
(27) \\
(28)\end{array}$ & & $\begin{array}{l}284 \\
240 \\
216 \\
144\end{array}$ \\
\hline
\end{tabular}

Table 3. Analysis of arg $^{+}$and pyr transductants for coinheritance of the unselected marker mms-13 after transduction using phage $\mathrm{G} 101$

\begin{tabular}{|c|c|c|c|c|c|}
\hline \multicolumn{2}{|c|}{ Transduction } & \multirow{2}{*}{\multicolumn{2}{|c|}{$\begin{array}{c}\text { Selected marker } \\
\text { (map location, } \\
\text { min) }\end{array}$}} & \multirow{2}{*}{$\begin{array}{c}\text { Coinheritance of } \\
\text { unselected marker } \\
m m s-13(\%)\end{array}$} & \multirow{2}{*}{$\begin{array}{l}\text { No. of } \\
\text { colonies } \\
\text { tested }\end{array}$} \\
\hline Donor & Recipient & & & & \\
\hline $\begin{array}{l}\text { G101(GMB143) } \\
\text { G101(GMB143) } \\
\text { G101(GMB143) }\end{array}$ & $\begin{array}{l}\text { PAO287 } \\
\text { PAO2001 } \\
\text { PAO486 }\end{array}$ & $\begin{array}{l}\arg B^{+} \\
\arg H^{+} \\
\operatorname{pyr} E^{+}\end{array}$ & $\begin{array}{l}(21) \\
(20) \\
(22)\end{array}$ & $\begin{array}{r}19 \\
0 \\
41\end{array}$ & $\begin{array}{l}252 \\
175 \\
674\end{array}$ \\
\hline
\end{tabular}

Table 4. Determination of gene order in the 20 to 22 min region of the

$P$. aeruginosa chromosome by analysis of arg $^{+}$, pyr $^{+}$and $\mathrm{pyr}^{+}$arg $^{+}$ transductants from the cross G101(GMB143) $\times$ GMC182

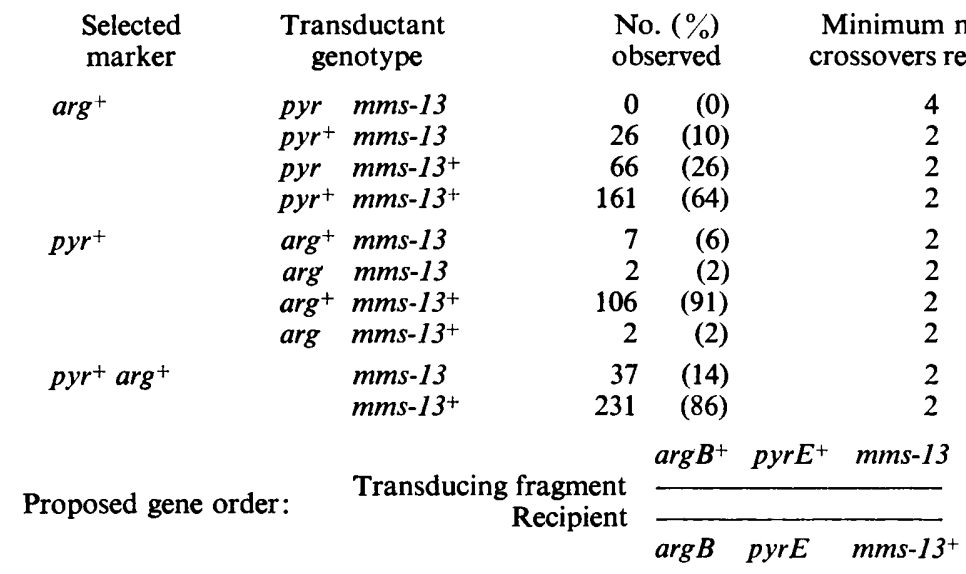

were obtained on the appropriate selective media. Purified recombinants were then patched on to nutrient agar plates containing MMS at a range of concentrations $(2,4$ and $8.5 \mathrm{~mm})$ to determine the number of MMS-sensitive clones, indicative of the $m m s-13$ allele. These results indicated that the locus determining radiation sensitivity and ATP-dependent nuclease deficiency (subsequently tested in several MMS-sensitive clones) is coinherited at a high frequency (74\%) with $\operatorname{argB1}$. $\operatorname{ArgB} 1$ is located at approximately $21 \mathrm{~min}$ on the $P$. aeruginosa chromosome (Haas et al., 1977).

The $m m s-13$ mutation was mapped more precisely by phage G101 transduction. A transducing lysate prepared on GMB143 was used to transduce strains PAO2001, PAO287 and PAO486 selecting for $\arg H^{+}, \arg B^{+}$and $p y r E^{+}$transductants, respectively. The map location of $\operatorname{argH}$ is at $20 \mathrm{~min}$ (Haas et al., 1977) and that of $p y r E$ is at $22 \mathrm{~min}$ (Holloway. 1978). The results of these experiments (Table 3 ) show that the $m m s-13$ mutant allele can be cotransduced by phage G101 with $\arg B(19 \%)$ and $p y r E(41 \%)$ but is unlinked to $\arg H$. The map order $\arg B-p y r E-m m s-13$ was confirmed by three-factor crosses (Table 4). 


\section{Table 5. Recombinational ability of strains GMC166 and PAO287 following conjugation (FP2) and transduction (G101)}

The donor strains were PAO170 for conjugation and PAO1 for transduction. Genotypes of the recipient strains were: GMC166, his-12 mms-13 ilv-202 met-28 str-1; PAO287, his-12 ilv-202 met-28 $\operatorname{argB1}$ str-1.

$\begin{array}{ccccc}\begin{array}{c}\text { No. of recombinants } \\ \text { per } 10^{8} \text { donor cells } \\ \text { in FP2 conjugation }\end{array} & \begin{array}{c}\text { No. of recombinants } \\ \text { per } 10^{8} \text { p.f.u. } \\ \text { Recipient } \\ \text { strain }\end{array} & \overbrace{i l v^{+}}^{\text {G101 transduction }} \\ \text { GMC166 } & 115 & 106 & \overbrace{i l v^{+}} & \text {met }^{+} \\ \text {PAO287 } & 494 & 347 & 24 & 3 \cdot 3 \\ & & & & 16\end{array}$

\section{Recombination ability}

To determine the recombination proficiency of a strain deficient in ATP-dependent DNAase, a multi-auxotrophic strain carrying the mutant allele $m m s-13$ was obtained after FP2 conjugation. This strain (GMC166) was used as a recipient in conjugation with the donor strain PAO170 (Kung \& Lee, 1975) and the number of $i l v^{+}$and $\mathrm{met}^{+}$recombinants was determined (Table 5). Both markers showed lower levels of recombination $\left(i l \nu^{+} 23 \%\right.$ and $\mathrm{met}^{+} 30 \%$ of the wild-type levels as observed in strain PAO287). The number of recombinants following transduction by phage G101 grown on wild-type PAO1 was also lower in the presence of the $m m s-13$ allele (ilv $v^{+9} \%$ and $m e t^{+} 20 \%$ of the wild-type PAO287 level).

Since the frequency of transfer of resistance to mercuric ions, conferred by the sex factor FP2 (Loutit, 1970), is similar for PAO287 and GMC166 (results not shown), it is unlikely that the decrease in recombination frequency in GMC166 is due to failure to form effective mating pairs. Furthermore, both GMC166 and PAO287 plate phage G101 with equal efficiencies (results not shown) indicating that the observed reductions in transduction frequencies were not due to loss of phage adsorption.

The possibility that the residual level of recombinants detected following FP2 conjugation with recipient GMC166 was due to the transfer of the $m m s-13^{+}$allele was tested. Of $100 \mathrm{ilv} \mathrm{v}^{+}$ and $100 \mathrm{met}^{+}$recombinants purified and tested, $2 \%$ were MMS-resistant. None of the $i \mathrm{lv}^{+}$ transductants tested were MMS-resistant. These results indicated that while transfer of the $m m s-13^{+}$marker was possible it was not responsible for the residual levels $(20 \%$ to $30 \%)$ of recombinants observed in conjugation and transduction experiments.

The presence of a low level of functional enzyme or a normal level of partially functional enzyme may explain the residual level of recombination. The presence of alternative pathways of recombination, as detected in E. coli (Clark, 1973), was not investigated.

The need to account for the degree of viability in strains involved in recombination experiments in $P$. aeruginosa led to an investigation of the viability of strains GMC166 and the parental strain PAO287. The average ratio of viable cells to total cells for PAO287 was $75 \%$ over the period sampled. In contrast, the ratio for GMC166 was $39 \%$. These results indicate that decreased cell viability (as measured by colony-forming ability) was associated with the $m m s-13$ (GMC166) mutant allele. This loss of viability may account in part for the recombination deficiency of the mutant following transduction and conjugation.

The phenotype of GMB143 shows a close similarity to the recombination-deficient $\mathrm{rec} B$ and $\mathrm{rec} C$ mutants of $E$. coli which have been found to lack an ATP-dependent nuclease (Barbour \& Clark, 1970) and to the add mutants in H. influenzae (Kooistra et al., 1976; Small et al., 1976; Setlow, 1977), so that in all three organisms a similar enzymic defect is correlated with similar pleiotropic effects. However, as in $H$. influenzae (Kooistra et al., 1976), the role of this enzyme in recombination is not clear because mutants lacking the enzyme still retain some recombination ability. The $P$. aeruginosa ATP-dependent nuclease 
has been shown by Miller \& Clark (1976) to be different from that of $E$. coli in that it does not attack denatured DNA either endonucleolytically or exonucleolytically. This ATPdependent nuclease activity in $P$. aeruginosa therefore cannot be directly equated with that of the $E$. coli $r e c B, \operatorname{rec} C$ gene product (exonuclease V). However, based on the properties of this mutant of $P$. aeruginosa it is possible that both enzymes are involved in repair and recombination but whether they act in a similar manner is open to further investigation.

This work was supported by grants from the Australian Research Grants Committee and by a Research and Training Grant from the Australian Institute of Nuclear Science and Engineering. The technical assistance of Robert Brown is gratefully acknowledged.

\section{REFERENCES}

Allen, R. J. L. (1940). The estimation of phosphorus. Biochemical Journal 34, 858-865.

Barbour, S. D. \& Clark, A. J. (1970). Biochemical and genetic studies of recombination proficiency in Escherichia coli. I. Enzymatic activity associated with $\mathrm{recB}^{+}$and recC $\mathrm{C}^{+}$genes. Proceedings of the National Academy of Sciences of the United States of America 65, 955-961.

ButTin, G. \& WRIGHT, M. (1968). Enzymatic DNA degradation in $E$. coli. Its relationship to synthetic processes at the chromosome level. Cold Spring Harbor Symposia on Quantitative Biology 33, 259-269.

Chandler, P. W. \& Krishnapillai, V. (1974). Isolation and properties of recombination-deficient mutants of Pseudomonas aeruginosa. Mutation Research 23, 15-23.

Clark, A. J. (1973). Recombination deficient mutants of E. coli and other bacteria. Annual Review of Genetics 7, 67-86.

Doly, J., Sasarman, E. \& Anagnostopoulos, C. (1974). ATP-dependent deoxyribonuclease in Bacillus subtilis and a mutant deficient in this activity. Mutation Research 22, 15-23.

Friedman, E. A. \& Smith, H. O. (1972). An adenosine triphosphate-dependent deoxyribonuclease from Hemophilus influenzae $\mathrm{Rd}$. I. Purification and properties of the enzyme. Journal of Biological Chemistry 247, 2846-2853.

Greth, M. L. \& Chevallier, M. R. (1973). Studies on ATP-dependent deoxyribonuclease of Haemophilus influenzae: involvement of the enzyme in the transformation process. Biochemical and Biophysical Research Communications 54, 1-8.

Haas, D., Holloway, B. W., Schamböck, A. \& LEISINGER, T. (1977). The genetic organisation of arginine biosynthesis in Pseudomonas aeruginosa. Molecular and General Genetics 154, 7-22.

Holloway, B. W. (1955). Genetic recombination in Pseudomonas aeruginosa. Journal of General Microbiology 13, 572-581.

Holloway, B. W. (1978). Isolation and characterization of an $\mathrm{R}^{\prime}$ plasmid in Pseudomonas aeruginosa. Journal of Bacteriology 133, 1078-1082.

Holloway, B. W., Krishnapillai, V. \& Morgan, A. F. (1979). Chromosome genetics of Pseudomonas. Microbiological Reviews 43, 73-102.

Kooistra, J., Small, G. D., Setlow, J. K. \& ShapanKa, R. (1976). Genetics and complementation of Haemophilus influenzae mutants deficient in adenosine $5^{\prime}$-triphosphate dependent nuclease. Journal of Bacteriology 126, 31-37.

KUNG, A. H. C. \& LeE, B. T. O. (1973). The isolation and characterization of radiation and chemicalmutagen sensitive mutants of Pseudomonas aeruginosa. Mutation Research 20, 175-190.

Kung, A. H. C. \& LeE, B. T. O. (1975). Genetic analysis of radiation sensitive and chemical mutagen sensitive mutants of Pseudomonas aeruginosa. Mutation Research 27, 191-199.

LehrbaCh, P. R., Kung, A. H. C. \& LeE, B. T. O. (1976). Mutants of Pseudomonas aeruginosa deficient in DNA polymerase I. Mutation Research 41, 391-394.

Lehrbach, P. R., Kung, A. H. C., L.eE, B. T. O. \& $J_{\text {ACOBY, G. A. (1977). Plasmid modification of }}$ radiation and chemical-mutagen sensitivity in Pseudomonas aeruginosa. Journal of General Microbiology 98, 167-176.

Loutir, J. S. (1970). Investigation of the mating system of Pseudomonas aeruginosa strain I. VI. Mercury resistance associated with the sex factor (FP). Genetical Research 16, 179-184.

Mazza, G., Fortunato, A., Ferrari, E., Canosi, V., Falaschi, A. \& Polsinelli, M. (1975). Genetic and enzymic studies on the recombination process of Bacillus subtilis. Molecular and General Genetics 136, 9-30.

MeE, B. J. \& LeE, B. T. O. (1967). An analysis of histidine requiring mutants of Pseudomonas aeruginosa. Genetics 55, 709-722.

MEE, B. J. \& LEE, B. T. O. (1969). A map order for hisI, one of the genetic regions controlling histidine biosynthesis in Pseudomonas aeruginosa, using the transducing phage F116. Genetics 62, 687-696.

Miller, R. V. \& Clark, A. J. (1976). Purification and properties of two deoxyribonucleases of Pseudomonas aeruginosa. Journal of Bacteriology 127, 794-802.

OH, S. \& SufokA, N. (1973). ATP-dependent deoxyribonuclease in Bacillus subtilis. 1. Purification and properties. Journal of Biological Chemistry 248, 7336-7344.

Oishi, M. (1969). An ATP-dependent deoxyribonuclease from Escherichia coli with a possible role in genetic recombination. Proceedings of the National Academy of Sciences of the United Statos of America 64, 1292-1299.

Pemberton, J. M. \& Clark, A. J. (1973). Detection 
and characterization of plasmids in Pseudomonas aeruginosa strain PAO. Journal of Bacteriology 114, 424-433.

Setlow, J. K. (1977). Properties of mutants of Haemophilus influenzae deficient in ATP-dependent deoxyribonuclease. In Modern Trends in Bacterial Transformation and Transfection. Edited by A. Portoles, R. Lopez \& M. Espinosa. Amsterdam: North-Holland Publishing Co.

Small, G. D., Setlow, J. K., Kocistra, J. \& SHAPANKA, R. (1976). Lethal effect of mitomycin $\mathrm{C}$ on Haemophilus influenzae. Journal of Bacterio$\log y 125,643-654$.

Stanisich, V. A. \& Holloway, B. M. (1969). Conjugation in Pseudomonas aeruginosa. Genetics 61, 327-339.

Van Dorp, B., Caulen, M. Th. E. \& Pouwels, P. H. (1974). Properties of an ATP-dependent deoxy- ribonuclease from Micrococcus luteus. A characterisation of the reaction products. Biochimica et biophysica acta 340, 166-176.

Vovis, G. F. \& Buttin, G. (1970a). An ATPdependent deoxyribonuclease from Diplococcus pneumoniae. I. Partial purification and some biochemical properties. Biochimica et biophysica acta 224, 29-41.

Vovis, G. F. \& Buttin, G. (1970b). An ATPdependent deoxyribonuclease from Diplococcus pneumoniae. II. Evidence for its involvement in bacterial recombination. Biochimica et biophysica acta 224, 42-54.

WILcox, K. W. \& SMITH, H. O. (1975). Isolation and characterization of mutants of Haemophilus influenzae deficient in an adenosine 5'-triphosphate-dependent deoxyribonuclease activity. Journal of Bacteriology 122, 443-453. 